\title{
Tumor-infiltrating Immune Cells in H\&E-stained Sections of Colorectal Cancer Tissue as a Reasonable Immunological Biomarker
}

\author{
SHINJI MATSUTANI, MASATSUNE SHIBUTANI, KIYOSHI MAEDA, HISASHI NAGAHARA, \\ TATSUNARI FUKUOKA, YASUHITO ISEKI, SHINICHIRO KASHIWAGI, \\ HIROAKI TANAKA, KOSEI HIRAKAWA and MASAICHI OHIRA
}

Department of Surgical Oncology, Osaka City University Graduate School of Medicine, Osaka, Japan

\begin{abstract}
Background: The density of tumor-infiltrating lymphocytes has been reported to reflect the antitumor immune status, and many reports have shown that tumor-infiltrating $C D 8^{+}$and total T-lymphocytes may be strong prognostic biomarkers in colorectal cancer. We previously reported that the density of tumor-infiltrating immune cells in hematoxylin and eosin $(H \& E)$-stained sections may be an easily available prognostic biomarker. However, it remains unclear whether the density of tumor-infiltrating immune cells in $H \& E$-stained sections accurately reflects the antitumor immune status. Patients and Methods: A total of 308 patients who underwent curative resection for stage II/III colorectal cancer were enrolled. The density of both tumor-infiltrating immune cells in $H \& E$-stained sections and tumor-infiltrating lymphocyte subsets was assessed by immunohistochemistry. Results: The density of tumor-infiltrating immune cells in H\&E-stained sections was significantly and positively correlated with that of tumorinfiltrating $\mathrm{CD}^{+} / \mathrm{CD}^{+} /$total T-lymphocytes. Conclusion: The density of tumor-infiltrating immune cells in $H \& E$-stained sections may be a reasonable immunological biomarker.
\end{abstract}

The density of tumor-infiltrating lymphocytes (TILs), which reflects the antitumor immune status, has been reported to be correlated with tumor progression and the clinical outcome in several malignancies, including non-small cell lung cancer, colorectal, esophageal, and urothelial cancer, and melanoma (18). In particular, the density of tumor-infiltrating $\mathrm{CD}^{+}$and total T-lymphocytes are reportedly correlated with the antitumor immune status of the host, and these values are used as a

Correspondence to: Masatsune Shibutani, 1-4-3 Asahi-machi, Abeno-ku, Osaka, 545-8585, Japan. Tel: +81 666453838, Fax: +81 666466450,e-mail: fbxbj429@ybb.ne.jp

Key Words: Tumor-infiltrating immune cells, H\&E, tumor-infiltrating T-lymphocytes, immunological biomarker, colorectal cancer. component of the 'Immunoscore', which is a powerful immunological biomarker in colorectal cancer $(9,10)$. On the other hand, an International TILs Working Group made recommendations for the standard methodology for evaluating tumor-infiltrating lymphocytes in hematoxylin and eosin (H\&E)-stained sections of breast cancer tissue (11). Based on those recommendations (11), we previously reported that the density of immune cells in the tumor stroma in H\&E-stained sections of colorectal cancer tissue was significantly correlated with the survival outcome after curative resection (12). Such a method of evaluating tumor-infiltrating immune cells using H\&E-stained sections is easy to apply in the clinical setting due to its convenience. However, it remains unclear whether the density of tumor-infiltrating immune cells in H\&E-stained sections accurately reflects the antitumor immune status. The reasons are as follows: Firstly, it is unclear whether the density of immune cells in H\&E-stained sections, which are mononuclear immune cells that include not only T-lymphocytes, but also plasma cells and B-cells, is actually correlated with that of $\mathrm{CD}^{+}$and total T-lymphocytes. Secondly, there are differences in the area assessed in evaluation using H\&E-stained sections and that using immunohistochemistry. Only the TILs in the tumor stroma are evaluated in H\&E-stained sections due to technical issues. In contrast, in immunohistochemistry, all TILs in both the tumor stroma and cancer cell nests are evaluated. Whether the density of immune cells in the tumor stroma in H\&E-stained sections reflects the antitumor immune status of the whole tumor is not clear. We planned this retrospective cohort study of 308 patients with stage II/III colorectal cancer in order to answer these questions.

\section{Patients and Methods}

Patients. A total of 308 patients who underwent curative resection for stage II/III colorectal cancer at the Department of Surgical Oncology of Osaka City University Hospital between 2007 and 2012 were enrolled. The data were analyzed retrospectively. Patients 
who underwent neoadjuvant therapy or emergency surgery for perforation or obstruction and those with coexisting inflammatory bowel disease were excluded. The resected sections were pathologically classified according to the seventh edition of the TNM classification of malignant tumors (13).

Evaluation of immune cells in H\&E-stained sections. The density of immune cells in H\&E-stained sections of colorectal cancer tissue was estimated according to the recommendations by the International TILs Working Group (11) as well as our previous study (12). The method is summarized as follows: we focused on the invasive margin of the tumor at low magnification and evaluated (semi-quantitatively) the percentage of the area of the tumor stroma that was occupied by mononuclear immune cells (at intervals of $10 \%)$ at high magnification $(\times 200)$ (Figure 1). Mononuclear immune cells (including lymphocytes and plasma cells) in the tumor stroma were defined as TILs. The density of TILs was evaluated in five different fields and the average density of TILs was calculated.

Immunohistochemistry. Immunohistochemical staining of CD4 and CD8 was performed as previously described $(14,15)$. The methods are summarized as follows. Tumor sections from surgically resected specimens from all of the enrolled patients were incubated with primary mouse monoclonal anti-CD4 antibodies (1:80 dilution; Dako, Glostrup, Denmark) at room temperature for 20 minutes, and primary mouse monoclonal anti-CD8 antibodies (1:100 dilution; Dako) at room temperature for $30 \mathrm{~min}$.

The immunohistochemically stained sections were then evaluated by a pathologist who was blinded to the clinical information. The number of $\mathrm{CD}^{+}$and $\mathrm{CD} 8+$ lymphocytes was counted in each location (i.e. in the tumor stroma, cancer cell nests, and in the whole microscopic field) at the invasive margin of the tumor at $\times 400$ magnification (Figure 2). The average number of $\mathrm{CD} 4^{+}$and $\mathrm{CD} 8^{+}$ lymphocytes in five randomly selected fields was then estimated. The sum of the number of $\mathrm{CD}^{+}$and $\mathrm{CD}^{+}$lymphocytes was defined as the total number of T-lymphocytes.

Statistical analysis. Associations between the density of stromal TILs and the number of lymphocytes $\left(\mathrm{CD} 4^{+}, \mathrm{CD}^{+}\right.$and total T-lymphocytes) were evaluated using Pearson's correlation analysis. The statistical analysis was conducted using the JMP ${ }^{\circledR}$ 13.0.0 (2016 SAS institute Inc., Cary, NC, USA). $p$-Values of less than 0.05 were considered to indicate statistical significance. The $\mathrm{R}$ values for the degree of correlation were classed as follows: $0.0 \leq \mathrm{r} \leq 0.2$, very weak; $0.2 \leq r \leq 0.4$, weak; $0.4 \leq r \leq 0.7$, moderate; $0.7 \leq r \leq 1.0$, strong.

Ethical considerations. This research conformed to the provisions of the Declaration of Helsinki. All patients were informed of the investigational nature of this research and provided their written informed consent. This research was approved by the Ethics Committee of Osaka City University (approval no. 3853).

\section{Results}

Patient characteristics. The patient characteristics are shown in Table I. The median age was 68 years (range $=21-96$ years). One hundred fifty-eight patients were male $(51 \%)$ and 150 were female (49\%). The tumor depth was T1-3 in the majority of patients $(66 \%)$. One hundred and sixty-six (54\%) patients were negative for lymph node metastasis.
Table I. Patient characteristics.

\begin{tabular}{lr}
\hline Clinicopathological factor & $\mathrm{n}=308$ \\
\hline Gender, $\mathrm{n}(\%)$ & \\
Male & $158(51 \%)$ \\
Female & $150(49 \%)$ \\
Age (years) & $68(21-96)$ \\
Median (range) & \\
Location of primary tumor, $\mathrm{n}(\%)$ & $169(55 \%)$ \\
Colon & $139(45 \%)$ \\
Rectum & \\
Tumor depth, n (\%)* & $204(66 \%)$ \\
T1-3 & $104(34 \%)$ \\
T4 & \\
Tumor diameter (cm) & $4.5(0.8-12.0)$ \\
Median (range) & \\
Histological type, $\mathrm{n}(\%)$ & $284(92 \%)$ \\
Well-, moderately differentiated & $24(7.8 \%)$ \\
Poorly differentiated, mucinous & \\
Lymphatic involvement, $\mathrm{n}(\%)$ & $83(27 \%)$ \\
Negative & $225(73 \%)$ \\
Positive & \\
Venous involvement, $\mathrm{n}(\%)$ & $242(79 \%)$ \\
Negative & $66(21 \%)$ \\
Positive & $166(54 \%)$ \\
Lymph node metastasis, n (\%) & $142(46 \%)$ \\
Negative & \\
Positive & \\
\hline
\end{tabular}

*According to TNM Classification of Malignant Tumors (seventh edition) (13).

The distribution of tumor-infiltrating T-lymphocytes. Regardless of the lymphocyte subsets, the number of lymphocytes infiltrating the cancer cell nests was extremely low and most T-lymphocytes were present in the tumor stroma (Table II).

Associations between the density of immune cells in $H \& E$ stained sections and the density of tumor-infiltrating $T$ lymphocytes subsets. The density of tumor-infiltrating immune cells in H\&E-stained sections was weakly positively associated with the density of CD4+ T-lymphocytes in the whole microscopic field and in the tumor stroma (whole microscopic field, $\mathrm{r}=0.26, p<0.001$; tumor stroma, $\mathrm{r}=0.26$, $p<0.001$ ) (Figure 3). The density of immune cells in the H\&Estained sections showed a relatively strong positive association with the density of $\mathrm{CD}^{+} \mathrm{T}$-lymphocytes in the whole microscopic field and in the tumor stroma (whole microscopic field, $\mathrm{r}=0.50, p<0.001$; tumor stroma, $\mathrm{r}=0.46, p<0.001$ ) (Figure 3). The density of immune cells in H\&E-stained sections was relatively strongly positively associated with the density of total T-lymphocytes in the whole microscopic field and in the tumor stroma (whole microscopic field, $\mathrm{r}=0.50$, $p<0.001$; tumor stroma, $\mathrm{r}=0.48, p<0.001$ ) (Figure 3). 

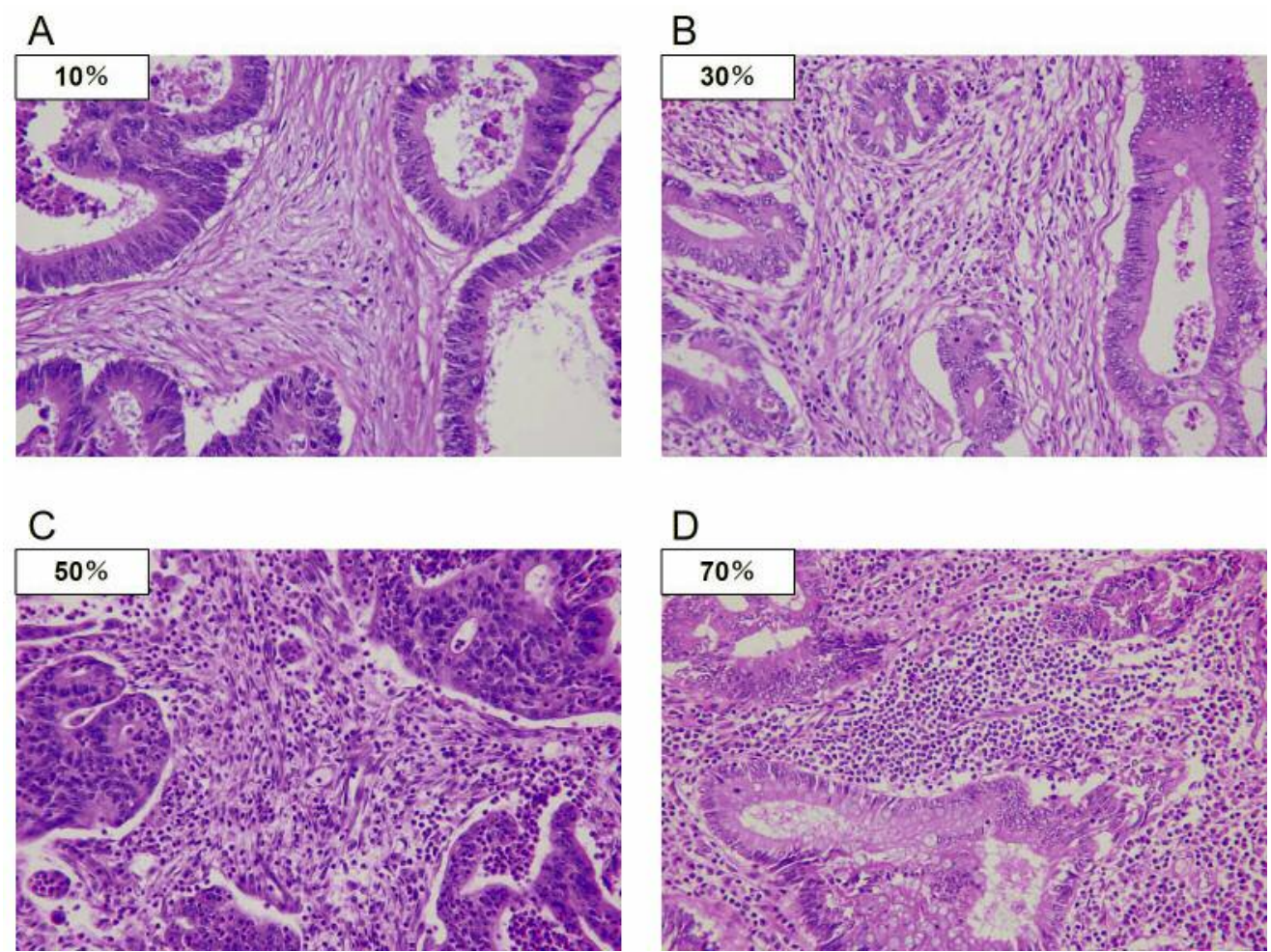

Figure 1. The evaluation of the density of tumor-infiltrating immune cells in the tumor stroma in hematoxylin and eosin-stained sections of colorectal cancer tissue. A: 10\%. B: 30\%. C: 50\%. D: 70\%. Magnification, $\times 200$.

A

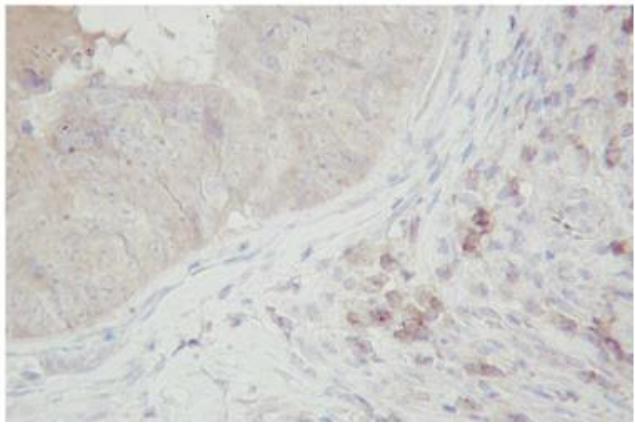

B

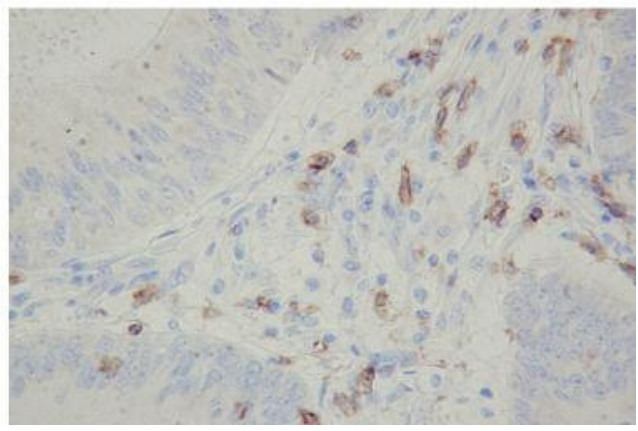

Figure 2. The immune marker expression of tumor-infiltrating T-lymphocytes in colorectal cancer. A: CD4. B: CD8. Magnification, x400.

\section{Discussion}

In this study, we made two important observations. Firstly, the density of the tumor-infiltrating immune cells in H\&Estained sections was positively associated with the density of tumor-infiltrating $\mathrm{CD}^{+}$and total T-lymphocytes, which has been reported to be significantly correlated with the survival outcome $(1,2,16,17)$. Secondly, as the number of Tlymphocytes infiltrating cancer cell nests was extremely low, the density of TILs in the tumor stroma alone in H\&Estained sections was significantly associated with the density of tumor-infiltrating T-lymphocytes in the whole tumor.

The current study showed a significant positive association between the density of tumor-infiltrating immune 
A

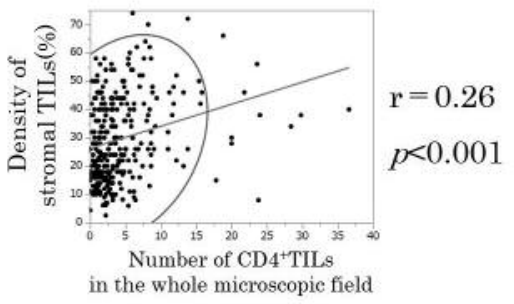

B

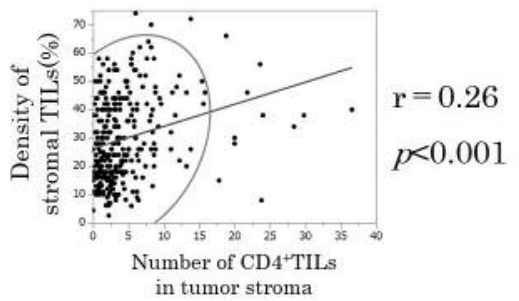

C

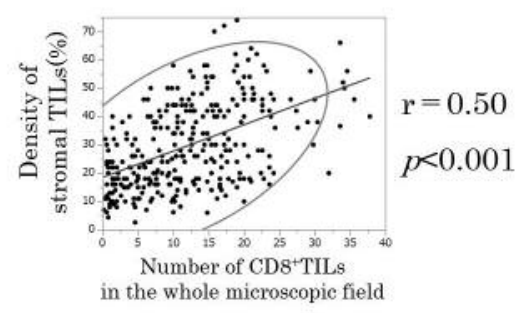

$\mathrm{D}$

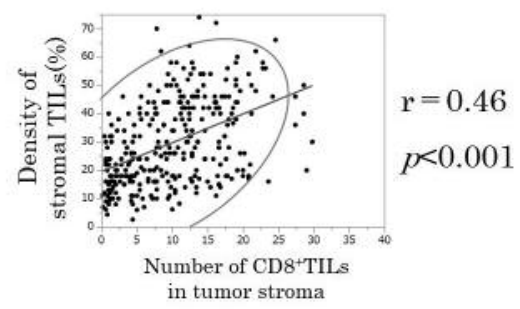

$\mathrm{E}$
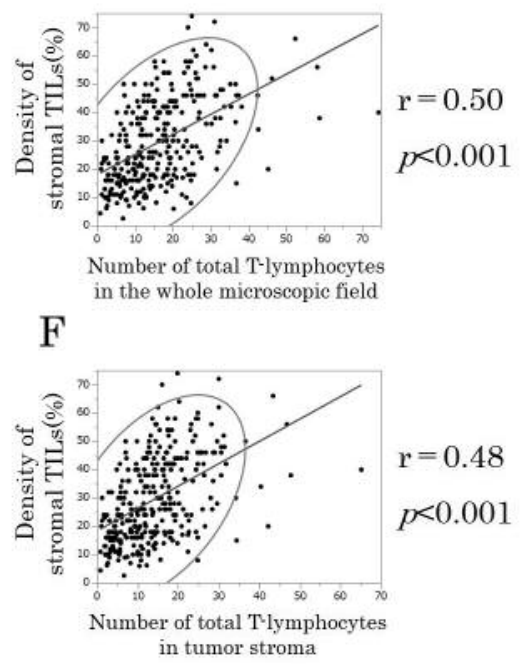

Figure 3. The associations between the density of hematoxylin and eosin-stained stromal TILs and the number of T-lymphocytes $\left(C D 4+, C D 8^{+}\right.$and total $C D 4^{+}+C D 8^{+}$T-lymphocytes).

Table II. The distribution of the T-lymphocytes in tumors.

\begin{tabular}{lccc}
\hline & \multicolumn{3}{c}{ Median number of TILs/field (range) } \\
\cline { 2 - 4 } Subgroup & Tumor stroma & Cancer cell nests & Whole field (tumor stroma+cancer cell nests) \\
\hline CD4 & $2.9(0-36.6)$ & $0(0-2.2)$ & $3.0(0-36.6)$ \\
CD8 & $9.6(0-29.8)$ & $0.6(0-16.4)$ & $11.1(0.2-37.8)$ \\
Total T-lymphocytes & $13.3(0.8-65.2)$ & $0.6(0-16.4)$ & $15.0(0.8-74.4)$ \\
\hline
\end{tabular}

TILs: Tumor-infiltrating lymphocytes.

cells in H\&E-stained sections and the density of tumorinfiltrating $\mathrm{CD}^{+}$and total T-lymphocytes. Some previous reports, including our previous own, demonstrated that the density of tumor-infiltrating immune cells in H\&E-stained sections of colorectal cancer tissue was an immunological biomarker that was associated with the survival outcome $(8$, 12, 18-20). However, it remains unclear whether the density of mononuclear immune cells, which includes not only Tlymphocytes, but also plasma cells and B-lymphocytes, in H\&E-stained sections of colorectal cancer tissue accurately reflects the antitumor immune status. Many authors have reported that the density of tumor-infiltrating $\mathrm{CD}^{+}$and total T-lymphocytes was significantly associated with the antitumor immune status and the survival outcome $(1,2,16$, 17). In this background, the density of tumor-infiltrating $\mathrm{CD}^{+}$and $\mathrm{CD}^{+}$T-lymphocytes is used as a component of the Immunoscore, an immunological prognostic scoring system $(10,21)$. On the basis of the associations between the density of immune cells in H\&E-stained sections and the number of $\mathrm{CD}^{+}$and total T-lymphocytes, we concluded that the density of immune cells in H\&E-stained sections may accurately reflect the antitumor immune status. Regarding $\mathrm{CD} 4^{+} \mathrm{T}$-cells, the functions of each $\mathrm{CD} 4^{+} \mathrm{T}$-cell subset in antitumor immunity differ. In concrete terms, T-helper 1 cells have been reported to enhance antitumor immunity $(16,22$, 23). However, the functions of T-helper 2 cells, T-helper 17 cells and regulatory $\mathrm{T}$-cells have differed among reports, being described as immunostimulatory, immunosuppressive and neutral depending on the type and stage of cancer $(1,22$, 24-26). In fact, some previous reports, including our own, showed that the density of tumor-infiltrating $\mathrm{CD}^{+}{ }^{+} \mathrm{T}-\mathrm{cells}$ was not associated with the survival outcome $(1,14)$. Moreover, mononuclear immune cells in cancer stroma in $\mathrm{H} \& \mathrm{E}$ sections, which were evaluated in the current study, 
include not only T-cells but also B-cells and plasma cells. Some studies have reported that tumor-infiltrating B-cells may enhance the antitumor immunity and be associated with a favorable clinical outcome $(27,28)$, while others have reported that B-cells may be a heterogeneous population with several functionally discrete subsets (28-30), and still others have reported that the functions of tumor-infiltrating B-cells and plasma cells remain unclear (11). Thus, there is no consensus concerning the functions of tumor-infiltrating B-cells and plasma cells. As described above, the mononuclear immune cells evaluated in the tumor stroma in $\mathrm{H} \& \mathrm{E}$ sections included several types of immune cells. However, we concluded that the density of the tumorinfiltrating immune cells in $H \& E$ sections might be an immunologically reasonable biomarker, as the density of the tumor-infiltrating immune cells in H\&E sections was associated with that of the tumor-infiltrating $\mathrm{CD}^{+}$and total T-cells, which are components of the Immunoscore (10).

The current study showed that the density of immune cells only in the tumor stroma (other than the immune cells infiltrating cancer cell nests) in H\&E-stained sections was significantly associated with the density of infiltrating T-lymphocytes in the whole tumor, because the number of T-lymphocytes infiltrating the cancer cell nests was extremely low. The recommendations on the evaluation of TILs in H\&E-stained sections of breast cancer tissue by the International TILs Working Group reported that the density of TILs in the tumor stroma alone may be a more useful and reproducible biomarker than the density of TILs in cancer cell nests (11). The reason for this was believed to be that the TILs in cancer cell nests are fewer and more heterogeneous than those in the tumor stroma alone, and it is difficult to count the number of TILs in cancer cell nests in H\&E-stained sections because it is difficult to distinguish the nuclei of cancer cells from those of mononuclear immune cells. Moreover, the scoring of TILs in cancer cell nests has been reported to produce no more information than that which can be gleaned from the TILs in the tumor stroma because the number of TILs in cancer cell nests is usually associated with the number of TILs in the tumor stroma. It was also reported that scoring TILs in the tumor stroma alone had a clear advantage because the density of tumor cells and their growth pattern do not affect the score. The number of T-lymphocytes in cancer cell nests was extremely low in colorectal cancer as well as breast cancer; it was reported that most tumor-infiltrating T-lymphocytes exist in the tumor stroma (31).

The current study is associated with certain limitations. Firstly, in cases of diffuse infiltrative colorectal cancer (such as signet ring cell carcinoma and undifferentiated carcinoma), which were quite rare, it was difficult to evaluate the area occupied by immune cells in the tumor stroma in $\mathrm{H} \& \mathrm{E}$ sections. The density of TILs may need to be evaluated by immunohistochemistry in such types of colorectal cancer. Secondly, although we estimated the average density of TILs in H\&E-stained sections from five different fields in order to allow the evaluation to be performed easily, evaluating the density of TILs over the whole tumor at a low magnification (e.g. $\times 100)$ might be a more suitable method for resolving the issue of heterogeneity in the tumor. Thirdly, although we evaluated the density of TILs in H\&E-stained sections semiquantitatively (every 10\%), according to the recommendations by the International TILs Working Group (11), the evaluation of the density of TILs in four levels as well as the KlintrupMakinen criteria (18) might be easier to perform and might be more useful in the clinical setting. Fourthly, although a previous report showed acceptable interobserver agreement between pathologists assessing TILs (32), the extent of the interobserver variability remains unclear.

The current study demonstrated that the density of tumorinfiltrating immune cells in H\&E-stained sections was positively associated with the density of $\mathrm{CD}^{+}$and total T-lymphocytes, which have been reported to be the strong prognostic biomarkers. The current study also demonstrated that the density of tumor-infiltrating immune cells in the tumor stroma alone in H\&E-stained sections was associated with the density of tumor-infiltrating T-lymphocytes in the whole tumor because the number of T-lymphocytes infiltrating the cancer cell nests was extremely low. Thus, we concluded that the density of tumor-infiltrating immune cells in the tumor stroma in H\&E-stained sections may be a reasonable immunological biomarker.

\section{Acknowledgements}

The Authors thank Brian Quinn who provided medical writing services on behalf of JMC, Ltd.

\section{References}

1 Fridman WH, Pages F, Sautes-Fridman C and Galon J: The immune contexture in human tumours: impact on clinical outcome. Nat Rev Cancer 12: 298-306, 2012

2 Pages F, Kirilovsky A, Mlecnik B, Asslaber M, Tosolini M, Bindea G, Lagorce C, Wind P, Marliot F, Bruneval P, Zatloukal $\mathrm{K}$, Trajanoski Z, Berger A, Fridman WH and Galon J: In situ cytotoxic and memory $\mathrm{T}$ cells predict outcome in patients with early-stage colorectal cancer. J Clin Oncol 27: 5944-5951, 2009.

3 Schumacher K, Haensch W, Roefzaad C and Schlag PM: Prognostic significance of activated CD8(+) T-cell infiltrations within esophageal carcinomas. Cancer Res 61: 3932-3936, 2001.

4 Wahlin BE, Sander B, Christensson B and Kimby E: CD8+ Tcell content in diagnostic lymph nodes measured by flow cytometry is a predictor of survival in follicular lymphoma. Clin Cancer Res 13: 388-397, 2007.

5 Angell $\mathrm{H}$ and Galon J: From the immune contexture to the Immunoscore: The role of prognostic and predictive immune markers in cancer. Curr Opin Immunol 25: 261-267, 2013. 
6 Horne ZD, Jack R, Gray ZT, Siegfried JM, Wilson DO, Yousem SA, Nason KS, Landreneau RJ, Luketich JD and Schuchert MJ: Increased levels of tumor-infiltrating lymphocytes are associated with improved recurrence-free survival in stage 1A non-smallcell lung cancer. J Surg Res 171: 1-5, 2011.

7 Pelletier MP, Edwardes MD, Michel RP, Halwani F and Morin JE: Prognostic markers in resectable non-small cell lung cancer: a multivariate analysis. Can J Surg 44: 180-188, 2001.

8 Shibutani M, Maeda K, Nagahara H, Fukuoka T, Iseki Y, Matsutani S, Kashiwagi S, Tanaka H, Hirakawa K and Ohira M: Tumor-infiltrating lymphocytes predict the chemotherapeutic outcomes in patients with stage IV colorectal cancer. In Vivo 32: 151-158, 2018.

9 Pages F, Mlecnik B, Marliot F, Bindea G, Ou FS, Bifulco C, Lugli A, Zlobec I, Rau TT, Berger MD, Nagtegaal ID, VinkBorger E, Hartmann A, Geppert C, Kolwelter J, Merkel S, Grutzmann R, Van den Eynde M, Jouret-Mourin A, Kartheuser A, Leonard D, Remue C, Wang JY, Bavi P, Roehrl MHA, Ohashi PS, Nguyen LT, Han S, MacGregor HL, Hafezi-Bakhtiari S, Wouters BG, Masucci GV, Andersson EK, Zavadova E, Vocka M, Spacek J, Petruzelka L, Konopasek B, Dundr P, Skalova H, Nemejcova K, Botti G, Tatangelo F, Delrio P, Ciliberto G, Maio M, Laghi L, Grizzi F, Fredriksen T, Buttard B, Angelova M, Vasaturo A, Maby P, Church SE, Angell HK, Lafontaine L, Bruni D, El Sissy C, Haicheur N, Kirilovsky A, Berger A, Lagorce C, Meyers JP, Paustian C, Feng Z, Ballesteros-Merino C, Dijkstra J, van de Water C, van Lent-van Vliet S, Knijn N, Musina AM, Scripcariu DV, Popivanova B, Xu M, Fujita T, Hazama S, Suzuki N, Nagano H, Okuno K, Torigoe T, Sato N, Furuhata T, Takemasa I, Itoh K, Patel PS, Vora HH, Shah B, Patel JB, Rajvik KN, Pandya SJ, Shukla SN, Wang Y, Zhang G, Kawakami Y, Marincola FM, Ascierto PA, Sargent DJ, Fox BA and Galon $\mathrm{J}$ : International validation of the consensus Immunoscore for the classification of colon cancer: A prognostic and accuracy study. Lancet 391: 2128-2139, 2018.

10 Galon J, Mlecnik B, Bindea G, Angell HK, Berger A, Lagorce C, Lugli A, Zlobec I, Hartmann A, Bifulco C, Nagtegaal ID, Palmqvist R, Masucci GV, Botti G, Tatangelo F, Delrio P, Maio M, Laghi L, Grizzi F, Asslaber M, D'Arrigo C, Vidal-Vanaclocha F, Zavadova E, Chouchane L, Ohashi PS, Hafezi-Bakhtiari S, Wouters BG, Roehrl M, Nguyen L, Kawakami Y, Hazama S, Okuno K, Ogino S, Gibbs P, Waring P, Sato N, Torigoe T, Itoh K, Patel PS, Shukla SN, Wang Y, Kopetz S, Sinicrope FA, Scripcariu V, Ascierto PA, Marincola FM, Fox BA and Pages F: Towards the introduction of the 'Immunoscore' in the classification of malignant tumours. J Pathol 232: 199-209, 2014.

11 Salgado R, Denkert C, Demaria S, Sirtaine N, Klauschen F, Pruneri G, Wienert S, Van den Eynden G, Baehner FL, PenaultLlorca F, Perez EA, Thompson EA, Symmans WF, Richardson AL, Brock J, Criscitiello C, Bailey H, Ignatiadis M, Floris G, Sparano J, Kos Z, Nielsen T, Rimm DL, Allison KH, Reis-Filho JS, Loibl S, Sotiriou C, Viale G, Badve S, Adams S, Willard-Gallo $\mathrm{K}$ and Loi $\mathrm{S}$ : The evaluation of tumor-infiltrating lymphocytes (TILs) in breast cancer: recommendations by an International TILs Working Group 2014. Ann Oncol 26: 259-271, 2015.

12 Iseki Y, Shibutani M, Maeda K, Nagahara H, Fukuoka T, Matsutani S, Kashiwagi S, Tanaka H, Hirakawa K and Ohira M: A new method for evaluating tumor-infiltrating lymphocytes (TILs) in colorectal cancer using hematoxylin and eosin (H-E)stained tumor sections. PLoS One 13: e0192744, 2018.
13 Sobin LH, Gospodarowicz MK and Wittekind C: UICC. TNM Classification of Malignant Tumors. Seventh Edition. New York, Wiley-Liss, 2009.

14 Matsutani S, Shibutani M, Maeda K, Nagahara H, Fukuoka T, Iseki $\mathrm{Y}$, Hirakawa $\mathrm{K}$ and Ohira $\mathrm{M}$ : Verification of the methodology for evaluating tumor-infiltrating lymphocytes in colorectal cancer. Oncotarget 9: 15180-15197, 2018.

15 Matsutani S, Shibutani M, Maeda K, Nagahara H, Fukuoka T, Nakao S, Hirakawa K and Ohira M: Significance of tumorinfiltrating lymphocytes before and after neoadjuvant therapy for rectal cancer. Cancer Sci 109: 966-979, 2018.

16 Galon J, Costes A, Sanchez-Cabo F, Kirilovsky A, Mlecnik B, Lagorce-Pages C, Tosolini M, Camus M, Berger A, Wind P, Zinzindohoue F, Bruneval $\mathrm{P}$, Cugnenc $\mathrm{PH}$, Trajanoski $\mathrm{Z}$, Fridman WH and Pages F: Type, density, and location of immune cells within human colorectal tumors predict clinical outcome. Science 313: 1960-1964, 2006.

17 Richards CH, Roxburgh CS, Powell AG, Foulis AK, Horgan PG and McMillan DC: The clinical utility of the local inflammatory response in colorectal cancer. Eur J Cancer 50: 309-319, 2014.

18 Klintrup K, Makinen JM, Kauppila S, Vare PO, Melkko J, Tuominen H, Tuppurainen K, Makela J, Karttunen TJ and Makinen MJ: Inflammation and prognosis in colorectal cancer. Eur J Cancer 41: 2645-2654, 2005.

19 Roxburgh CS, Salmond JM, Horgan PG, Oien KA and McMillan DC: Tumour inflammatory infiltrate predicts survival following curative resection for node-negative colorectal cancer. Eur $\mathbf{J}$ Cancer 45: 2138-2145, 2009.

20 Huh JW, Lee JH and Kim HR: Prognostic significance of tumorinfiltrating lymphocytes for patients with colorectal cancer. Arch Surg 147: 366-372, 2012.

21 Galon J, Pages F, Marincola FM, Angell HK, Thurin M, Lugli A, Zlobec I, Berger A, Bifulco C, Botti G, Tatangelo F, Britten CM, Kreiter S, Chouchane L, Delrio P, Arndt H, Asslaber M, Maio M, Masucci GV, Mihm M, Vidal-Vanaclocha F, Allison JP, Gnjatic S, Hakansson L, Huber C, Singh-Jasuja H, Ottensmeier C, Zwierzina H, Laghi L, Grizzi F, Ohashi PS, Shaw PA, Clarke BA, Wouters BG, Kawakami Y, Hazama S, Okuno K, Wang E, O'Donnell-Tormey J, Lagorce C, Pawelec G, Nishimura MI, Hawkins R, Lapointe R, Lundqvist A, Khleif SN, Ogino S, Gibbs P, Waring P, Sato N, Torigoe T, Itoh K, Patel PS, Shukla SN, Palmqvist R, Nagtegaal ID, Wang Y, D'Arrigo C, Kopetz S, Sinicrope FA, Trinchieri G, Gajewski TF, Ascierto PA and Fox BA: Cancer classification using the Immunoscore: A worldwide task force. J Transl Med 10: 205, 2012.

22 Tosolini M, Kirilovsky A, Mlecnik B, Fredriksen T, Mauger S, Bindea G, Berger A, Bruneval P, Fridman WH, Pages F and Galon J: Clinical impact of different classes of infiltrating Tcytotoxic and helper cells (Th1, Th2, Treg, Th17) in patients with colorectal cancer. Cancer Res 71: 1263-1271, 2011.

23 Camus M, Tosolini M, Mlecnik B, Pages F, Kirilovsky A, Berger A, Costes A, Bindea G, Charoentong P, Bruneval P, Trajanoski $\mathrm{Z}$, Fridman $\mathrm{WH}$ and Galon $\mathrm{J}$ : Coordination of intratumoral immune reaction and human colorectal cancer recurrence. Cancer Res 69: 2685-2693, 2009.

24 Liu J, Duan Y, Cheng X, Chen X, Xie W, Long H, Lin Z and Zhu B: IL-17 is associated with poor prognosis and promotes angiogenesis via stimulating VEGF production of cancer cells in colorectal carcinoma. Biochem Biophys Res Commun 407: 348354, 2011. 
25 Michel S, Benner A, Tariverdian M, Wentzensen N, Hoefler P, Pommerencke T, Grabe N, von Knebel Doeberitz M and Kloor M: High density of FOXP3-positive T-cells infiltrating colorectal cancers with microsatellite instability. Br J Cancer 99: 18671873, 2008.

26 Frey DM, Droeser RA, Viehl CT, Zlobec I, Lugli A, Zingg U, Oertli D, Kettelhack C, Terracciano L and Tornillo L: High frequency of tumor-infiltrating FOXP3(+) regulatory T-cells predicts improved survival in mismatch repair-proficient colorectal cancer patients. Int J Cancer 126: 2635-2643, 2010.

27 Berntsson J, Nodin B, Eberhard J, Micke P and Jirstrom K: Prognostic impact of tumour-infiltrating B-cells and plasma cells in colorectal cancer. Int J Cancer 139: 1129-1139, 2016.

28 Tsou P, Katayama H, Ostrin EJ and Hanash SM: Thecells in tumor immunityf B-cells in tumor immunity. Cancer Res 76: 5597-5601, 2016.

29 Nelson BH: CD20+ B-cells: The other tumor-infiltrating lymphocytes. J Immunol 185: 4977-4982, 2010.
30 Fremd C, Schuetz F, Sohn C, Beckhove P and Domschke C: BCell-regulated immune responses in tumor models and cancer patients. Oncoimmunology 2: e25443, 2013.

31 Lee WS, Park S, Lee WY, Yun SH and Chun HK: Clinical impact of tumor-infiltrating lymphocytes for survival in stage II colon cancer. Cancer 116: 5188-5199, 2010.

32 Swisher SK, Wu Y, Castaneda CA, Lyons GR, Yang F, Tapia C, Wang X, Casavilca SA, Bassett R, Castillo M, Sahin A and Mittendorf EA: Interobserver agreement between pathologists assessing tumor-infiltrating lymphocytes (TILs) in breast cancer using methodology proposed by the International TILs Working Group. Ann Surg Oncol 23: 2242-2248, 2016.

Received October 12, 2018

Revised November 1, 2018

Accepted November 2, 2018 